\title{
UTJECAJ KONVENCIJSKOG PRAVA I PRAVA EUROPSKE UNIJE NA ZAŠTITU PRAVA STRANKE U UPRAVNOM SPORU
}

Dr. sc. Bosiljka Britvić Vetma, docent

Pravni fakultet Sveučilišta u Splitu
UDK: $342.922:: 061.1 \mathrm{EU}$

342.922:341.231.14(4)

Ur.. 4. veljače 2016.

Pr.: 11. ožujka 2016.

Izvorni znanstveni rad

\section{Sažetak}

Cilj je ovog rada utvrditi čimbenike koji utječu na zaštitu prava stranke u upravnom sporu. Upravni sudovi u Republici Hrvatskoj moraju u svom djelovanju istovremeno uključivati pravo koje razvija Sud u Strasbourgu, kvalificirano kao konvencijsko pravo, a i pravo zajednice koje razvija Sud u Luxembourgu. U tu svrhu, autor razmatra utjecaj konvencijskog prava i prava Europske unije na zaštitu prava stranke u upravnom sporu.

Ključne riječi: pravo stranke u upravnom sporu, konvencijsko pravo, pravo Europske unije.

\section{1. $U V O D$}

Pravo stranke u upravnom sporu ovisi o nizu vanjskih čimbenika povezanih s obavljanjem sudačke dužnosti. Pravo stranke predstavlja proces koji upravno sudstvo - ma koliko ono bilo neovisno - više ne može zaobići. Navedeno nužno upućuje na Europsku konvenciju za zaštitu ljudskih prava ${ }^{1}$ koja o ovoj tematici progovora isključivo u kontekstu pravednosti postupka. To govori u prilog tezi da je teško ocijeniti opseg prava stranke pred upravnim sudovima, budući da to podrazumijeva ocjenu niza proturječnih faktora, što čini svaki pokušaj sistematizacije osjetljivim, čak i neuspješnim. Pravo se stranke, na kraju krajeva, ne može analizirati kao homogena i nedjeljiva cjelina. Naprotiv, riječ je o složenom pojmu koji se sastoji od više dijelova „složno“ usmjerenih prema konačnom rezultatu - zaštiti prava stranke u upravnom sporu.

Mišljenja smo kako je pravo stranke u upravnom sporu danas posebno važno, u vremenu, kada se uloga upravnog suca bitno mijenja. Slijedom navedenoga, u najnovije vrijeme, pitanje prava stranke nameće se kao jedno od najvažnijih pravnih

1 Narodne novine, Međunarodni ugovori, br. 18/97, 6/99, 14/02, 13/03, 9/05, 1/06, 2/10. 
pitanja uopće, kao glavna sastavnica kvalitete pravne zaštite, važan aspekt prava na pošteno suđenje, a iz čega slijedi povjerenje građana u konkretni pravni sustav. Pravo stranke u upravnom sporu ovisi o nizu čimbenika i o njihovu međudjelovanju. Tako pravo stranke u upravnom sporu ovisi o kvaliteti pravnog obrazovanja $\mathrm{i}$ izobrazbi sudacate o dodjeli odgovarajućih ljudskih, financijskih i materijalnih resursa. Daljnji element koji utječe na pravo stranke jest postupak vođenja predmeta. Postupak mora biti jasan, transparentan i predvidljiv, a upravni sudac mora biti sposoban organizirati i voditi sudski postupak aktivno i ispravno. Odluka se mora donijeti u razumnom roku. Međutim, brzina postupka nije jedini čimbenik koji se pritom mora uzeti u obzir, jer sudske odluke moraju štititi pravo pravičnog suđenja, socijalne harmonije i pravne sigurnosti. Usmena rasprava ${ }^{2}$ se mora održati kad god to pravna praksa Europskog suda za zaštitu ljudskih prava propisuje i mora biti u skladu sa zahtjevima Europske konvencije za zaštitu ljudskih prava te tako osigurati strankama u sporu pravično suđenje. Pravično vođenje postupka, ispravna primjena pravnih načela i ocjena činjenične podloge kao i izvršnost, ključni su elementi koji pridonose zaštiti prava stranke u upravnom sporu. Sudska odluka mora biti razumljiva i sastavljena jasnim i jednostavnim jezikom, s tim da se svakom sucu dopušta da izabere svoj vlastiti stil ili da se koristi standardiziranim modelima. ${ }^{3}$

Sudske odluke u načelu moraju biti obrazložene. Obrazloženje mora uključiti tumačenje pravnih načela, brinuti o osiguranju pravne sigurnosti i pravne dosljednosti. Utemeljenost sudske odluke nadzire se prizivnim i nadzornim postupkom koji je dostupan u nacionalnim sudovima te pravom dostupnosti Europskom sudu za zaštitu ljudskih prava. ${ }^{4}$ Iako Europska konvencija za zaštitu ljudskih prava ne inzistira na dvostupnjevanosti, ako je žalbeni postupak predviđenim nacionalnim propisima, on mora zadovoljiti uvjete članka 6. Europske konvencije za zaštitu ljudskih prava. ${ }^{5}$

2 Europska konvencija za zaštitu ljudskih prava pod pravom na javno suđenje, u pravilu, podrazumjeva i pravo na usmenu raspravu. Pravo na usmenu raspravu posebno je važno kada upravni sud sagledava osporena činjenična pitanja. Izostajanje usmene rasprave u prvoj i posljednoj instanci pred upravnim sudom mogu opravdati samo izuzetne okolnosti. Načelno stranke imaju pravo da se odreknu usmene rasprave, i to izričito ili prešutno. Međutim, kako je to potvrdio Europski sud za zaštitu ljudskih prava, u predmetu Schuler-Zgraggen, takvo odricanje nema djelovanje ako se suprostavlja javnom interesu.

3 Preporuka Vijeća Europe kao bitne elemente pravičnog suđenja navodi: razumnost trajanja sudskog postupka, jednakost sredstava kojima raspolažu stranke u postupku, pristup spisima predmeta, kontradiktornost postupka, ispitivanje pravnih i činjeničnih pitanja u vezi $\mathrm{s}$ predmetom spora, javnost postupka, obrazlaganje i objavljivanje sudskih odluka i pravni lijekovi.

4 Iako Europska konvencija za zaštitu ljudskih prava ne obvezuje na postojanje žalbenog postupka, ipak Preporuka (2004) 20 Vijeća Europe naznačuje kako bi odluka suda, bar u važnim slučajevima, trebala biti predmet žalbe višem sudu, osim ako se predmet direktno upućuje višem sudu u skladu s nacionalnim propisima. Upravnosudska zaštita bi, prema navedenom, trebala biti dvostupanjska.

5 Osim što doprinosi boljoj sudskoj zaštiti, dvostupnjevanost u upravnim sporovima doprinosi i ujednačenosti upravnosudske prakse. 
Sudski sustav u cjelini mora se pozorno razmotriti kako bi se ocijenila zaštita prava stranke u upravnom sporu. Posebnu pozornost valja posvetiti duljini, transparentnosti i vođenju postupka.

Pitanje troškova može biti posebno važno ako stranka želi ostvariti svoje pravo na upravnosudsku zaštitu. Isto tako, djelotvorni pristup sudu, u smislu njegovih troškova, podrazumijeva i pravo na pravnu pomoć ${ }^{6}$ kako bi se jamčila sudska zaštita i strankama koje ne mogu snositi troškove. ${ }^{7}$ Isto je tako potrebno da se stranci u upravnom sporu osigura pravo na zastupnika ${ }^{8}$ i pravo na uvid u sve relevantne dokumente. ${ }^{9}$

Razvoj upravnog spora u Republici Hrvatskoj ide u smjeru jačanja pojedinačnih prava stranke u upravnom sporu. Cilj je Zakona o upravnim sporovima ${ }^{10}$ osigurati sudsku zaštitu prava i pravnih interesa fizičkih i pravnih osoba i drugih stranaka povrijeđenih pojedinačnim odlukama ili postupanjima javnopravnih tijela. Zakon o upravnim sporovima Republike Hrvatske sadržava cijeli niz odredaba kojima se ostvaruje pravo stranke na sudjelovanje u sporu. Pravo stranke u upravnom sporu prema Zakonu o upravnim sporovima uređeno je normama o pokretanju spora, zastupanju tužitelja, o dužnostima i ovlasti predlaganja činjenica koje treba utvrditi te dokaze kojima to može biti učinjeno, kao i izjašnjenja o činjeničnim navodima i dokaznim prijedlozima drugih stranaka, o ovlasti rješavanja spora bez rasprave, o sudjelovanju na raspravi, o radnjama u sporu, o ovlasti predlaganja odgodnog učinka tužbe odnosno privremene mjere, o komuniciranju suda i tužitelja, o pravima tužitelja na podnošenje redovnih i izvanrednih pravnih lijekova te o pravu na iniciranje postupaka upravnosudske ocjene zakonitosti općeg akta. Prava stranke podrazumijevaju i to da svaka stranka ima pravo iznositi vlastitu argumentaciju i eventualna dokazna sredstva, mora biti upoznata s argumentacijom i dokaznim sredstvima protivne stranke, a kada se vodi usmena rasprava, odnosno

6 Povelja o temeljnim pravima Europske unije, članak 47., jamči pravo na besplatnu pravnu pomoć.

„Pravna pomoć osigurava se za osobe koje nemaju dostatna sredstva, ako je takva pomoć potrebna za osiguravanje učinkovitoga pristupa pravosuđu.“

7 To mogu biti sudske pristojbe, te troškovi vođenja samog postupka (angažiranje punomoćnika, dolasci na raspravu, itd.). Kako bi se omogućio što širi pristup sudu, Preporuka (2004) 20 u tom smislu predviđa da ukupni troškovi pristupa sudu ne smiju biti prepreka za pokretanje sudskog postupka.

8 Povelja o temeljnim pravima Europske unije, članak 47., jamči pravo zastupanja.

„Svatko ima mogućnost da bude savjetovan, branjen i zastupan.“

9 Pravo na uvid u dokumentaciju smatra se preduvjetom pravičnog suđenja. Tako je Europski sud za zaštitu ljudskih prava, predmet Schuler - Zgraggen, istaknio kako stranka mora imati pristup spisima predmeta u obliku u kojem je javnopravno tijelo proslijedilo upravnom sudu. Za pravični postupak nužno je da su spisi proslijeđeni na vrijeme (Schuler-Zgraggen protiv Switzerland, te Bendenoun protiv Francuske). Tužba se mora proslijediti tužitelju i svim zainteresiranim stranama. Svi dokazi koje sud prihvati moraju biti na raspolaganje svim strankama u sporu (Ruiz - Mateos, Europski sud za zaštitu ljudskih prava).

10 Narodne novine, br. 20/10, 143/12, 152/14. 
utvrđuje činjenično stanje, mora biti pozvana i saslušana. ${ }^{11}$ Tek je u drugom planu osiguranje objektivnog prava. Objektivno pravo, u pravilu se štiti kroz odlučivanje o subjektivnim pravima tužitelja. Štiteći subjektivna prava tužitelja povrijeđena pojedinačnim odlukama ili postupanjem javnopravnih tijela, štiti se objektivni pravni poredak. ${ }^{12}$

Za zaštitu prava stranke u upravnim predmetima važno je stajalište izraženo u odluci Ustavnog suda Republike Hrvatske. U predmetnoj se odluci navodi: „Pravila i sredstva dokazivanja čine dio cjeline postupovnih pravila upravnog postupka, sadržanih u Zakonu o općem upravnom postupku i kao takva neodvojiva su sastavnica postupovnih jamstava pravičnog suđenja, zaštićenih Ustavom. Ustavni sud štiti ustavno jamstvo pravičnog suđenja (odlučivanja) ispitujući eventualno postojanje postupovnih povreda u postupcima pred sudovima i drugim državnim tijelima, odnosno tijelima koje imaju javne ovlasti. Pružajući tu zaštitu, Ustavni sud sagledava cjelokupni postupak kao jedinstvenu cjelinu te ocjenjuje je li on bio vođen na način koji podnositelju osigurava pravično suđenje (odlučivanje), odnosno je li tijekom postupka počinjena povreda takvog značenja da postupak kao cjelinu čini nepravičnim za podnositelja. Sagledavajući konkretan slučaj s tog stajališta, Ustavni sud primjećuje da je postupanje nadležnih upravnih tijela i Upravnog suda, utvrđeno u konkretnom slučaju (neosnovano ograničenje dokaznih sredstava, odnosno mogućnosti utvrđivanja relevantnih činjenica u skladu s načelom materijalne istine, uz bitne nedostatke $\mathrm{u}$ obrazlaganju zauzetih stajališta), dovelo do povrede podnositeljeva ustavnog prava na pravično suđenje (odlučivanje) s aspekta općih jamstava sadržanih u članku 29. stavak 1. Ustava, koja jamstva moraju biti poštovana i u postupku sudske kontrole zakonitosti pojedinačnih akata uprave iz članka 19. stavka 2. Ustava. “"13

Zbog ograničenog opsega rada razmatraju se samo pojedini čimbe-nici koji utječu na zaštitu prava stranke u upravnom sporu.

\section{KONVENCIJSKO PRAVO I PRAVO EUROPSKE UNIJE}

Europska konvencija za zaštitu ljudskih prava i temeljnih sloboda potpisana je u Rimu 4. svibnja 1950. godine. Republika Hrvatska ratificirala je Konvenciju 5. studenog 1997. godine, pa stoga Konvencija, sukladno članku 141. Ustava Republike Hrvatske predstavlja dio njezina unutarnjeg pravnog poretka. Prema Sudu u Strasbourgu ova Konvencija predstavlja „ustavni alat europskog poretka“ ${ }^{14}$

11 Vidi: Medvedović, Dragan, Komentar Zakona o upravnim sporovima, Novi sustav upravnog sudovanja, Novi informator, Zagreb, 2012.

12 Ibid., str. 32.

13 Vidi odluka Ustavnog suda Republike Hrvatske broj: U-III-3937/2001. od 14. prosinca 2011., U-III-2009. od 3. studenog 2001.

14 Europski sud za zaštitu ljudskih prava, 18. siječnja 1978., Irska protiv Ujedinjenog Kraljevstva; 23. ožujka 1995., Loizidou protiv Turske. 
dok Sud u Luxembourgu opisuje ugovore Zajednice kao „Ustavnu povelju pravne Zajednice"..$^{15}$

U okviru Vijeća Europe i Europske unije, Sudovi u Strasbourgu i Luxembourgu zauzimaju posebno mjesto jer se temelje na ugovorima čiji je učinak s obzirom na nacionalna prava posebno proširen. Odredbe tih ugovora, ne samo da imaju prednost pred nacionalnim pravom, već ih je nacionalni sudac obvezan izravno primjenjivati, te se na njih može pozvati svaka zainteresirana osoba. U dva europska sustava, istovremeno postoji podudarnost između podvrgavanja vladavini prava i obveze uzimanja u obzir rješenja europskih sudova nadležnih za njegovu provedbu. Njihova nadležnost je obvezujuća i ostvaruje se u odnosu na nacionalne sudove kao i u odnosu na „sva javnopravna tijela“. ${ }^{16}$

Prema tome, Europska unija, sveobuhvatnije koristi ovlasti koje potiču na rastuću integraciju tako što pojedincima daje prava na koja se mogu izravno pozvati pred nacionalnim upravnim sudovima.

Međutim, ova dva sustava počivaju na različitim konceptima. S jedne strane radi se o „logici suradnje“ koju provodi Sud u Luxembourgu, dok, s druge strane, Sud u Strasbourgu primjenjuje „logiku nadzora“. No, u oba slučaja sudska praksa zauzima značajno mjesto.

Upravno pravo Republike Hrvatske mora istovremeno uključivati pravo koje razvija Sud u Strasbourgu, kvalificirano kao konvencijsko pravo, a i pravo zajednice koje razvija Sud u Luxembourgu. Kada se radi o Sudu u Strasbourgu, budući da ne postoje mogućnosti prethodnog pitanja, usklađivanje može biti osjetljivije i trenja ne predstavljaju iznimku. Najznačajniji primjer odnosi se na objašnjenja koja je Sud dao pojmu „,pravičnog suđenja“. Kontrola koju sud provodi nad aktima nacionalnog suca osobito je osjetljiva, kada se određeni problem odnosi na povredu članka 6. stavka 1. Konvencije u različitim elementima. Članak 6. stavak 1., koji se ponekad može kombinirati s člankom 13. o pravu na djelotvorno pravno sredstvo, glasi: „Radi utvrđivanja svojih prava i obveza građanske naravi ili u slučaju podizanja optužnice za kazneno djelo protiv njega svatko ima pravo da na zakonom ustanovljeni neovisni i nepristrani sud pravično, javno i u razumnom roku ispita njegov slučaj. Presuda se mora izreći javno...".

To su, svakako, posebne odredbe, koje se odnose na upravnosudske postupke, a koje najstrože utječu na pravo stranke u upravnom sporu. U primjeni ,prava na pošteno suđenje“ koje sažima odredbe članka 6. stavka 1., Sud u Strasbourgu postupa „ako ne kao dodatni stupanj sudovanja, onda barem kao tijelo za provedbu nadzora nad rješenjem nacionalnog suca, s mogućnošću osporavanja istog“". ${ }^{17}$

Prema Sudu u Strasbourgu, pravo na „pošteno suđenje“ samo je procesni prijevod načela prednosti prava sadržanog u Preambuli Konvencije, ${ }^{18}$ koje je kao

15 Sud Europske unije, 14. prosinca 1991., mišljenje 1/91.

16 Abraham, Ronny, Les Cours européennes: Luxembourg et Strasbourg, Devant les juridictions européennes, POUVOIRS, Paris, br. 96/2001, str. 145.

17 Ibid., str. 148.

18 Europski sud za zaštitu ljudskih prava, 26. rujna 1977., Sunday Times. 
takvo uvršteno „među temeljna načela demokracije““. ${ }^{19}$ Time, promaknut u red „referentne norme demokratskog društva“, ${ }^{20}$ članak 6. postaje odredba čije se povrede najčešće navode. Ipak, „formulacija koja se koristi u članku 6. stavku 1. daleko od toga da je savršeno jasna (i koja uopće nije istovjetna na francuskom ili engleskom jeziku)... izazvala je brojne komentare i složeni razvoj sudske prakse“". ${ }^{21}$

Prema Državnom savjetu Republike Francuske ako se odredbe Konvencije, u načelu, izravno primjenjuju (self executing), pravilo mora biti dovoljno precizno i bezuvjetno. ${ }^{22}$ Kao i bilo koji drugi sličan tekst, Konvenciju tumače i primjenjuju Sud u Strasbourgu i nacionalni sudovi „bez obzira na nacionalne kvalifikacije““.23 Osim toga, sud je uvelike rabio metodu finalističkog ili „teleološkog“ tumačenja članka 6., dodatno smatrajući da njegove presude imaju za cilj ne samo donijeti presudu u slučajevima za koje mu se uputi zahtjev nakon iscrpljivanja nacionalnih pravnih lijekova, već i zbog pojašnjenja i razvoja normi Konvencije. Upravo tom sudskom praksom Sud „svakodnevno dodatno natapa nacionalne pravne poretke“. ${ }^{24}$

Članak 6. stavak 1. kojem je svrha pravičnost suđenja odnosi se na pravosudni ideal, na ideju „dobre pravde“ ili još na „dobru upravu u pravosuđu“. Prema tome i za Sud u Strasbourgu ograničena primjenjivost ne bi odgovarala cilju i svrsi ovog teksta.

Članak 6. stavak 1. prirodno se primjenjuje na situacije u kojima element privatnog prava zauzima ključno mjesto. No, ako se radi o građanskom obilježju prava ili obveze i o osporavanjima do kojih može doći, Sud je vrlo rano prihvatio kako se njihova privatnost mora ocijeniti neovisno o prirodi pobijane mjere, kvaliteti stranaka, važećem pravu i pravosudnom poretku nadležnom za njihovo razumijevanje. ${ }^{25}$ Stoga se smatra da pravo stranke ima građansko obilježje, bez obzira na sudski poredak u državama u kojima je ovlašten da donosi odluke i bez obzira na (građansku, komercijalnu ili upravnu) narav pravila temeljem kojih treba riješiti osporavanje. ${ }^{26}$ Ono što pripada upravnom sporu prema nacionalnom pravu

19 Europski sud za zaštitu ljudskih prava, 21. veljače 1975., Goldec protiv Ujedinjeno Kraljevstvo.

20 Ibid.

21 J. DUTHEIL de la ROCHERE, Droit au juge, accès à la justice européenne, POUVOIRS, Paris, br. 96/2001, str. 126.

22 Francuski Državni savjet, 23. travnja 1997., GISTI.

23 Chapus, Rene, Droit du contentieux administratif, Montchrestien, Paris, 2006., 12. izd., str. 131.

24 Lichè, F., Potvin-Solis L., Raynouard, A., Le dialogue entre les juges européens et nationaux : incantation ou réalité?, Bruxelles, Bruylant, 2004., str. 242.

25 Europski sud za zaštitu ljudskih prava, 16. srpnja 1971., Ringeisen protiv Austrije.

26 Drugim riječima, sama činjenica da pitanje podliježe javnom pravu ne mora nužno isključivati oslanjanje na članak 6. stavak 1 . Sud je usvojio autonomni pojam ,građanskog obilježja“ dotične obveze ili osporavanja, a to može zakomplicirati pa čak i omesti nacionalna prava na različitim stupnjevima. Ono što je ,upravno“ prema nacionalnom zakonodavstvu treba se ponekad smatrati kao da ima „građansko“ obilježje. Isto vrijedi i za kazneni element članka 6. stavka 1. kojeg Sud također samostalno tumači. Tako primjerice „stegovni“ sporovi prema nacionalnom pravu mogu se smatrati podložnima pojmu ,podizanja optužnice za kazneno 
dovodi se u pitanje autonomnim pojmovima koji su se razvili u sudskoj praksi Suda u Strasbourgu i zbog ekstenzivnog shvaćanja i usvajanja ,građanske“ i „kaznene“ naravi.

Međutim, autonomni pojmovi omogućuju dobivanje ujednačene primjene Konvencije time što se zahtjevima članka 6. stavkom 1. daje najšire moguće područje primjene. No, još je potrebno da ove autonomne pojmove o postupovnim propisima prihvate i nacionalni sudovi. Osim ovih tvrdnji, primijećeno je da „Sud sve više teži uključivanju odgovornosti javnopravnog tijela u područje primjene članka 6. stavka 1., bez razlikovanja je li šteta posljedica materijalnih činjenica ili upravnih rješenja“" ${ }^{27}$

Pravo na pošteno suđenje kako ga Sud u Strasbourgu uzima u širem smislu, predstavlja kombinaciju nekoliko pojedinačnih prava: pravo na suca ili pristup sudu, pravo na presudu koja sadrži jamstva iz članka 6. stavka 1. koja se široko tumače i pravo na izvršenje presude. Propisi koji moraju biti posebno ispunjeni, nalažu da spor riješi sud koji je zakonom uspostavljen i koji mora biti neovisan i nepristran, da je sam postupak pravičan i da je u prisutnosti stranaka, da su ročišta u načelu javna te da je trajanje spora razumno.

\section{PRAVO NA SUCA I DJELOTVORNI PRAVNI LIJEK}

Povelja o temeljnim pravima Europske unije, članak 47., jamči pravo na djelotvorni pravni lijek ${ }^{28}$ i pravično suđenje. Prva dva stavka spomenutog članka vrlo su slična odredbama članka 6. Europske konvencije za zaštitu ljudskih prava.

„Svatko čija su prava i slobode, zajamčeni pravom Unije, prekršeni, ima pravo na učinkoviti pravni lijek pred sudom, u skladu s uvjetima utvrđenima ovim člankom. Svatko ima pravo na pravično, javno suđenje u razumnom vremenskom roku pred neovisnim i nepristranim sudom, prethodno osnovanim u skladu sa zakonom.“

djelo“ zbog naravi prekršaja i ozbiljnosti pretrpljene kazne. Vidi: Europski sud za zaštitu ljudskih prava, 8. lipnja 1976., Engel protiv Nizozemske.

Primjerice, u francuskom pravu, iako su rezultat represije, stegovni postupci ne spadaju nužno u kaznene stvari. Mnogi postupci mogu se povezati s građanskim stvarima, a događa se, istina rijetko, da ne pripadaju ni građanskim ni kaznenim elementima iz članka 6.

27 Tako ako je Državni savjet trenutačno u suglasnosti s glavnim smjernicama Suda u Strasbourgu i ako je upravno sudska praksa uključila poglede europskog suca o poštenom suđenju, to je učinjeno pod cijenu značajnog proširenja djelokruga članka 6. stavka 1. u upravnom sporu. Upravo kako bi izbjegao nagli raskid s tradicionalnim nacionalnim pravom Državni savjet se htio poslužiti širokim ovlastima u tumačenju presuda Suda u Strasbourgu. Međutim, budući da se europska sudska praksa razbistrila i stabilizirala, upravni sud mogao se samo pridružiti proširenom pojmu djelokruga članka 6. stavka 1.

Chapus, Rene, op. cit., str. 133.

28 Preporuka (2004) 20 Vijeća Europe zahtijeva da se strankama dopusti razuman rok za iznošenje stvari pred sud. Drži se da prekratak rok previše, može omogućiti stranku da podnese tužbu. Određivanje prikladnog roka je u uzajamnoj vezi s jamstvom na djelotvorni pristup sudu. 
U praksi Europskog suda utvrđeno je da djelotvornost sudske zaštite ima tri aspekta: pristup odgovarajućem sudu, pravo na privremenu zaštitu i pravo na naknadnu štete. U pogledu pristupa sudu, pravilo je da ako ne postoji mogućnost pokretanja postupak pred Sudom Europske unije, sudska se zaštita mora osigurati pred nacionalnim sudom. Ovo načelo utvrđeno je presudom Borelli iz 1992. godine. Prema shvaćanju iznesenom u presudi Borelli, nacionalni sustav mora osigurati sudsku zaštitu prava zajamčenih propisima Europske unije bez obzira na nacionalna pravila o legitimaciji i pravnom interesu. Prema načelu djelotvornosti, nacionalna pravila postupka ne smiju učiniti ostvarivanje prava zajamčenih propisima Europske unije praktično nemogućim ili pretjerano teškim. ${ }^{29}$

Pravo na pošteno suđenje kakvo je zajamčeno odredbama članka 6. stavka 1. Europske konvencije za zaštitu ljudskih prava, prije svega uključuje pristup sudu. ${ }^{30}$ S obzirom na značaj koju pravo na pošteno suđenje ima u svakom demokratskom društvu, pravo pristupa upravnim sudovima predstavlja bitan element, koji mora biti konkretan i djelotvoran, a ne samo teorijski. Sud u Strasbourgu, u svojoj presudi od 1. ožujka 2002., Kutić protiv Hrvatske, ističe kako pravo na suca predstavlja donošenje pravomoćne presude. Nadalje, Europski je sud za zaštitu ljudskih prava u presudi od 24. studenog 2004., Beaumartin protiv Francuske, naveo da djelotvorno pravno sredstvo podrazumijeva obvezu suđenja, što zabranjuje da na sudsku odluku utječe mišljenje javnopravnih tijela. ${ }^{31}$ Sud u Strasbourgu tome dodaje da sud mora imati nadležnost „pune jurisdikcije“ kako bi svome djelovanju pružio najveću moguću učinkovitost. Drugim riječima, mora moći dati odgovor na sva činjenična i pravna pitanja postavljena u sporu i eventualno reformirati osporenu mjeru. ${ }^{32}$

29 To se posebno odnosi na tzv. fatalne rokove (Prema Europskom sudu, to pravilo treba primjeniti i kad je rok razuman, ali je propuštanje nastalo zbog obmanjivanja od strane javnopravnih tjela. Tako je u predmetu Emmot tužiteljica tražila retroaktivnu isplatu doprinosa za invalidnost za period u komu Direktiva 79/7 o progresivnoj primjeni načela jednakosti postupanja između muškaraca i žena u pitanjima socijalne sigurnosti nije bila primjenjiva u Irskoj, te je ona trpjela diskriminaciju po osnovi spola. Nadležno javnopravno tijelo je obavijestilo da odluka u njenom slučaju ne može biti donesena dok Europski sud ne donese odluku u nekom drugom, sličnom slučaju. Međutim, kada je konačno pokrenula spor, to je tijelo odlučilo da je ona propuštanjem roka izgubila pravo na sudsku zaštitu. ili pravila dokazivanja, na primjer obrnuti teret dokazivanja ili ograničenja u pogledu dokaznih sredstava, (u odluci u predmetu Amministrazione delle Finanze dello State v. San Giorgio s.p.a., Europski je sud savjetovao talijanski sud da primjeni pravilo o izvođenju dokaza kojima je bio uvjetovan povrat poreza utvrđenog suprotnim propisima Europske unije, po kome je trebalo dokazati da porez nije prijavljen na krajnjeg korisnika. Ispunjenje tog uvjeta bilo bi pretjerano teško, te da je tako povređeno načelo djelotvorne sudske zaštite) u stvarima koja su regulirana pravom Europske unije.

$30 \mathrm{U}$ francuskom upravnom pravu, pravo na suca ustanovljeno je vrlo rano u općem načelu prava. Kao takvo ,pristup pravdi ne pojavljuje se na potpuno eksplicitan način kao pravo u Europskoj konvenciji“".

31 Vidi Europski sud za zaštitu ljudskih prava, 24. studenog 2004., Beaumartin protiv Francuske.

32 Vidi Europski sud za zaštitu ljudskih prava, 23. listopada 1995., Gradinger protiv Austrije; 18. veljače 1997., Mauer protiv Austrije. 
Odredbe članka 6. stavka 1. uključuju i druge zahtjeve koji proizlaze iz prava na dobro sudovanje. Među njima se nalazi nekoliko pravila koja jamče nesmetano odvijanje spora, a koje treba navesti i koja su mogla dovesti do odstupanja s obzirom na upravni postupak, a koja su popratile više ili manje mučne prilagodbe.

Europska konvencija za zaštitu ljudskih prava nalaže svim državama potpisnicama, bez obzira na njihov pravosudni sustav, sintetizirana postupovna pravila u svom članku 6. stavak 1. o pravu na pošteno suđenje. Godine 2001. tadašnji predsjednik Suda u Strasbourgu rekao je da ,sudska praksa Suda još uvijek rijetkost u pogledu prava na sud, neovisnost i nepristranost upravnih sudova, a još veća rijetkost u pogledu pravičnosti postupka, javne naravi rasprava i razumnog roka". ${ }^{33}$

Tako primjerice, kontradiktornost formalno nije među zahtjevima članka 6. stavka 1. Konvencije. Jednostavno je propisano da se slučaj mora pravično saslušati. Podrazumijeva se da stranke moraju biti ravnopravne i ne može se ni zamisliti pošteno suđenje bez načela kontradiktornosti s obzirom na to da $\mathrm{u}$ upravnom postupku, načelo kontradiktornosti, bitna, nastoji osigurati ravnopravnost stranaka pred sucem.

U pravu Europske unije, načelo djelotvornosti zahtijeva da nacionalna postupovna pravila u praksi ne čine nemogućim ili iznimno teškim ostvarivanje prava koja pojedincima daje pravni poredak Unije. ${ }^{34}$ Nacionalni sudovi su tako obvezni tumačiti i primjenjivati nacionalna postupovna pravila na način koji omogućuje strankama u postupku da imaju djelotvorno pravno sredstvo kako bi se omogućilo osiguranje prava koja proizlaze iz europskih pravnih propisa. ${ }^{35}$ Isto tako, treba spomenuti da Sud Europske unije priznaje sudsku kontrolu kao izraz „općeg načela prava koje se nalazi u temeljima ustavnih tradicija zajedničkih državama članicama. "36

Međutim, iz prava Europske konvencije za zaštitu ljudskih prava potječe pravo na djelotvorni pravni lijek. Članak 13. Konvencije izričito priznaje to pravo: ,svatko čija su prava i slobode koji su priznati u ovoj konvenciji povrijeđena ima pravo na djelotvorna pravna sredstva pred domaćim državnim tijelom čak i u slučaju kad su povredu počinile osobe koje su djelovale u službenom svojstvu“. Ovaj je članak imao izvjesni utjecaj na razvoj nacionalnog prava. S obzirom na svrhu koja predstavlja analiza izvršnosti rješenja upravnih sudova, ne radi se o razmatranju članka 13. u svim njegovim dimenzijama nego o usporednoj studiji prava na djelotvorni pravni lijek iz članka 13. Europske konvencije za zaštitu ljudskih prava s onom koja se odnosi na pravo izvršenja sudskih odluka. Istina je da ova usporedba

33 Costa, Jean-Paul, Le principe (d'impartialité) vu par la CEDH, 6/2001, A.J.D.A, Paris, 2001., str. 516.

34 Sud Europske unije, 10. travnja 2003, Steffensen, C-276/01; Sud Europske unije, 3. rujna 2009., Fallimento Olimpiclub, C-208.

35 Sud Europske unije, 23. travnja 1986., Zeleni protiv Europskog parlamenta; Sud Europske unije, 27. veljače 2007., Gestoras Pro Amnistia protiv Savjeta.

36 Sud Europske unije, 15. ožujka 1986., Johnston. 
ne bi imala previše smisla do prije petnaestak godina. Zapravo je jedan drugi članak Konvencije, članak 6. stavak 1., taj koji je tada skrenuo pozornost podnositelja zahtjeva i sudaca. Međutim, situacija se stubokom promijenila s važnom presudom Kudla protiv Poljske iz 2000. godine.

Ako se danas smatra da je djelotvorno izvršenje sudskih odluka čimbenik kredibiliteta pravosudnog sustava i jamstvo ljudskih prava, tek se neizravno, sa zakašnjenjem i nepotpuno članak 13. Europske konvencije za zaštitu ljudskih prava mogao nametnuti kao alat za njegovu obranu. Međutim, čini se da je pravo na djelotvorni pravni lijek tek postupno od djelomičnoga prava stekao status punog prava.

Utvrđivanje ovog razvoja dovelo nas je na put priznavanja prava na izvršenje sudskih odluka koja se prvo provodila „bez “ članka 13., a koja se danas provodi „u“ članku 13. Konvencije.

\subsection{Učinkovitost upravnosudske odluke kroz njezino izvršenje}

Izvršenje upravnosudskih odluka očigledno je ključno pitanje, snažno povezano $\mathrm{s}$ pravom stranke u upravnom sporu. Kako zajamčiti kvalitetu sudske odluke, osim njezinim izvršenjem? ${ }^{37}$ Pravo na pravično suđenje pretpostavlja pravo na izvršenje sudskih odluka čim one postanu pravomoćne i obvezujuće, u protivnom članak 6. Europske konvencije za zaštitu ljudskih prava $\mathrm{i}$ temeljnih sloboda ne bi imao nikakav koristan učinak. Upravo je taj koncept, vezan uz učinkovitost sudovanja, prihvatio Europski sud za za zaštitu ljudskih prava u čuvenoj presudi Hornsby protiv Grčke, ${ }^{38}$ kada je povezao obvezu izvršenja sudskih odluka s pravom na pravično suđenje. Uistinu u samoj formulaciji članka 6. stavka 1. Europske konvencije za zaštitu ljudskih prava ne stoji da države potpisnice imaju obvezu izvršenja sudskih odluka, ali je logično da ona u ime prvenstva prava ili težnje za učinkovitošću prava na pristup sudu sudjeluje u definiciji pravičnog postupka. Drugim riječima, povreda obveze koja proizlazi iz dinamičnog tumačenja članka 6., stavka 1. sudaca u Strasbourgu predstavlja, čitavo desetljeće, povredu prava na pravično suđenje jednako kao i povreda obveze za nepristranošću ili obveze suđenja u razumnom roku. Pravo na izvršenje sudskih

37 O izvršenju u hrvatskom upravnom pravu vidi: Staničić, Frane, Učinak vođenja upravnog spora na izvršnost upravnih odluka: privremene mjere $i$ odgodni učinak tužbe, Zbornik radova Pravnog fakulteta u Splitu, god. 52, 1/2015., str. 159.-173.; Đerđa, Dario, Izvršsenje upravnosudskih odluka u Hrvatskom i usporednom pravu, Zbornik radova Pravnog fakulteta u Splitu, god. 52, 1/2015., str. 131.-157; Horvat, Božidar, Upravni spor od podnošenja tužbe do izvršenja - sporna pitanja u praksi, Zbornik radova Pravnog fakulteta u Splitu, god. 52, 1/2015., str. 221.-242.; Rajko, Alen, Razlozi neizvršenja odluka upravnog suca i sredstva pravne zaštite u slučaju neizvršenja, Zbornik radova Pravnog fakulteta u Splitu, god. 52, 1/2015., str. 243.-258

38 Više o predmetnoj odluci vidi: Marko, Šikić, Lana, Ofak, Pravo na izvršenje upravnosudskih odluka kao jamstvo poštenog suđenja, Zbornik radova Pravnog fakulteta u Splitu, Split, god. 52, 1/2015., str. 203.-221 
odluka time pridonosi tako da jamči pravo na pravično suđenje i na taj način daje novu dimenziju kvaliteti sudovanja. Izvršenje upravnosudskih odluka smatra se sastavnim dijelom suđenja, a neizvršenje presuda u razumnom roku posebno se kvalificira kao povreda ,prava na sud“ iz članka 6. stavka 1. Europske konvencije za zaštitu ljudskih prava.

\subsubsection{Priznavanje prava na izvršnost sudskih odluka ,bez“ članka 13. Konvencije}

\subsubsection{Pravo koje proizlazi iz članka 6. stavka 1.}

Pravo na izvršenje sudskih odluka prvo je bilo vezano uz članak 6., stavak 1. Konvencije, a Europski sud za zaštitu ljudskih prava oslanjao se na načelo prednosti prava. No, kao što ističe profesor Frédéric Sudre „neizvršenje sudskih odluka stvara situaciju koja je nespojiva s načelom prednosti prava koje je u samim temeljima Konvencije“. ${ }^{39}$ Prvostupanjski sud Europske unije usvojio je slično obrazloženje za priznavanje ovoga prava. ${ }^{40}$

Tako je presudom Horsnby protiv Grčke od 19. ožujka 1997. u pošteno suđenje uključeno pravo na izvršenje sudskih odluka u razumnom roku. Sud primjećuje da se u ovom slučaju kašnjenje od više od šest mjeseci za djelotvorno izvršenje odluke može definirati kao prekomjerno, iako priznaje da određene naložene obveze mogu zahtijevati više vremena za svoju provedbu. U presudi se navodi da pravo na pošteno suđenje podrazumijeva pravo na izvršenje sudskih odluka: ,izvršenje presude ili odluke bez obzira na to o kojem se sudu radi, treba se smatrati sastavnim dijelom postupka u smislu članka 6.“. Prema mišljenju Suda, pravo na pošteno suđenje bilo bi „iluzorno“ kada bi pravni poredak države ugovornice dopuštao da pravomoćna i obvezujuća sudska odluka ostane neizvršena na štetu jedne strane. Prema tome, neizvršenje konačne presude ima za posljedicu povredu članka 6 . stavka 1.

Stoga Sud ocjenjuje da ako se ne poduzmu mjere potrebne za usklađivanje s pravomoćnom i ovršnom sudskom odlukom tijekom razdoblja od pet godina, time su nacionalna javnopravna tijela lišila odredbe članka 6. stavka 1. Konvencije svakoga korisnog učinka. Zatim, u predmetu koji se odnosi na odbijanje javnopravnog tijela da pomogne policijskim snagama pri izvršenju naloga za prisilno iseljenje, Sud je potvrdio da je „pravo na izvršenje presuda“ sastavni dio „prava na sud“ ${ }^{41}$

\subsubsection{Pravo podređeno članku 6. stavku 1.}

Općenito, kad je nastupilo kršenje normativne odredbe Konvencije, prigovor proizašao iz povrede prava na djelotvorni pravni lijek smatrao se suvišnim. ${ }^{42}$

39 Sudre, Frédéric, Droit européen et international des droits de l'homme, PUF, Paris, 2012.

40 Sud Europske unije, 19. ožujka 1997., Mentos Isidoro protiv Oliveira.

41 Europski sud za zaštitu ljudskih prava, 11. siječnja 2000., Lunari protiv Italije.

42 Ibid. 
Iako članak 13. jamči pravo na pravni lijek pred nacionalnim tijelom, u slučaju kršenja prava ili slobode sadržanih u konvenciji ili njezinim protokolima, on kao takav nije bio neovisan i njegov opseg bio je ograničen na prava i slobode koje priznaje konvencijski sustav. Prema tome, na njega se nije moglo odvojeno pozvati već ga je trebalo obvezatno kombinirati s odredbom iz Konvencije na čije se kršenje poziva.

Nekoliko drugih elemenata su ograničavali, a i dalje nastavljaju djelomično ograničavati, primjenjivost članka 13., tako da se čini da je članak 6. Konvencije dugo uspijevao „konfiscirati“ pravo na izvršenje sudskih odluka.

Prvo, članak 13. govori o pravu na djelotvorni pravni lijek pred „domaćim javnopravnim tijelom" koje ne mora biti sudsko tijelo. Upravo europski sudac in concreto odlučuje može li se pravni lijek smatrati djelotvornim. Članak 13. predstavljen je kao lex generalis u odnosu na lex specialis članka 6. koji, naprotiv, sadrži skup bitnih postupovnih jamstava.

Drugo, strogi uvjeti za primjenu članka 13. umanjuju njegov opseg. U tužbenom zahtjevu koji bi se pozivao samo na povredu članaka 6. i 13., primjenjivost članka 13. ne može nadoknaditi neprimjenjivost članka $6{ }^{43}$ Međutim, može se dogoditi da se primjenjuje u sklopu tužbenog zahtjeva koji bi navodio povredu materijalnog prava bez obzira na utvrđivanje povrede spomenutog prava. ${ }^{44}$

Veliki broj ovih tvrdnji i primjedbi pripada prošlim vremenima. U posljednjih petnaestak godina, razvoj sudske prakse Suda zapravo je članak 13. učinila glavnim pokretačem za priznavanje prava na izvršenje sudskih odluka.

\subsubsection{Priznavanje prava na izvršenje sudskih odluka ,u“ članku 13. Konvencije}

\subsubsection{Razvoj sudske prakse}

Dovršetak normizacije prava na djelotvorni pravni lijek i „potvrđivanje autonomnosti prava na djelotvorni pravni lijek" uglavnom su rezultat presude Kudla protiv Poljske od 26. listopada $2000 .{ }^{45} \mathrm{U}$ spomenutoj presudi Sud prihvaća ispitati pritužbu proizašlu iz povrede članka 13. zato što nije predviđeno pravno sredstvo koje omogućuje podnositelju zahtjeva da potvrdi svoje pravo na suđenje u razumnom roku.

Zbog preokreta u sudskoj praksi, Europski sud za zaštitu ljudskih prava je u ovom predmetu presudio da u slučaju povrede prava na razuman rok suđenja iz članka 6. Konvencije, podnositelj zahtjeva mora moći imati djelotvorni pravni lijek pred domaćim tijelom koji mu omogućuje da se žali zbog te povrede. Sud naknadno provjerava je li nastupila povreda prava na razuman rok u smislu članka 6., u slučaju

43 Europski sud za zaštitu ljudskih prava, 9. srpnja 2002, Cinar protiv Turske.

44 Europski sud za zaštitu ljudskih prava, 20. rujna 2005., Akat protiv Turske.

Les grands arrêts de la Cour européenne des droits de l'homme, PUF, Paris, 2011, str. 447 454.

45 Europski sud za zaštitu ljudskih prava, 26. listopada 2000., Kudla protiv Poljske. 
potvrdnog odgovora, postoji li u nacionalnom pravu djelotvorno pravno sredstvo u smislu članka 13. koje omogućuje da se žali zbog te povrede. S obzirom na značajan broj zahtjeva upućenih Sudu u Strasbourgu zbog nepriznavanja razumnog roka, osobito u okviru upravnog spora o državnoj službi, ova sudska praksa ima za posljedicu prisiljavanje podnositelja zahtjeva da iscrpi sva domaća pravna sredstva (Europska konvencija za zaštitu ljudskih prava, članak 35., stavak 1.) prije nego što uputi zahtjev Europskom sudu za ljudska prava, pod uvjetom da postoji djelotvorni domaći pravni lijek.

Francuska sudska praksa tome se posredno prilagodila, Državni savjet danas priznaje - kako bi ispunio kriterij djelotvornosti domaćeg pravnog lijeka jednostavnu pogrešku kako bi nadoknadio štetu uslijed prekomjernog trajanja postupaka pred upravnim sudovima, ${ }^{46}$ a to je promjena koju je Europski sud uzeo u obzir. ${ }^{47}$

Zatim, vezano uz dva grčka predmeta, ${ }^{48}$ Sud je podsjetio da se pravni lijek ne može smatrati djelotvornim u smislu članka 13. budući da je uprava odbila ili zanemarila izvršiti presudu koju su donijeli nacionalni sudovi.

Jedan od predmeta, tj. predmet Zazanis zaslužuje podrobniji prikaz. ${ }^{49}$ Podnositelji zahtjeva bili su grčki državljani, vlasnici zemljišta uključenog u plan grada kao građevinsko zemljište 1970.- ih godina, ali je u općinski katastar to zemljište upisao kao sastavni dio šumskog područja 1980.-ih godina. Oni su s građevinskim poduzećem potpisali ugovor koji predviđao izgradnju višekatnice na svom zemljištu 1990.-ih godina. To je poduzeće ishodilo građevinsku dozvolu, koju je, međutim, grčki Državni savjet poništio zbog toga što poduzeće prethodno nije ishodilo dozvolu za sječu stabala koja su se nalazila na tom zemljištu. Poduzeće je bezuspješno predavalo zahtjeve za sječu prije nego što je podnijelo žalbu Državnom savjetu koji je, u odluci iz 2000., prihvatio žalbu i smatrao da su svi dokumenti predani i vratio predmet upravi kako bi ona donijela odluku o zahtjevu za sječom stabala. Usprkos ovoj odluci, općina je uporno zahtijevala od poduzeća da ispuni uvjete koji nisu predviđeni zakonom i smanjila je za polovicu površinu građevinskog zemljišta. Zatim je ministar za zaštitu okoliša donio dekret o izmjeni korištenja spornog zemljišta u ,zelenu površinu“. Podnositelji zahtjeva su na temelju članaka 6. stavak 1. i 13. Konvencije prijavili odbijanje tijela vlasti da se usklade s presudom Državnog savjeta od 17. kolovoza 2000. kojom je poništena odluka o odbijanju dodjele urbanističke dozvole. Nakon preispitivanja okolnosti u ovom slučaju, Sud je smatrao da je ravnateljstvo za urbanizam odredilo nove uvjete koji su izjednačeni s neispunjavanjem presude Državnog savjeta. Nadalje,

46 Francuski Državni savjet, 28. srpnja 2002., Garde des Sceaux protiv Magiera, RFDA, Paris, 2002 .

47 Europski sud za zaštitu ljudskih prava, 21. listopada 2003., Broca et Texier-Micault protiv Francuske.

Europski sud za zaštitu ljudskih prava, 24. rujna 2010., Sartory protiv Francuske.

48 Europski sud za zaštitu ljudskih prava, 18. studenog 2004., Fotopoulou protiv Grčke; Europski sud za zaštitu ljudskih prava, 18. studenog 2004., Zazanis i drugi protiv Grčke.

49 Navodi Europskog suda za zaštitu ljudskih prava. 
Sud je utvrdio da je odluka ministra za zaštitu okoliša, koji je prekvalificirao sporno zemljište u „zelenu površinu“, tri godine nakon presude Državnog savjeta, izjednačena $\mathrm{s}$ formalnim nalogom za izvlaštenje koji lišava presudu njezine biti. Prema tome, Sud je zaključio da je nastupila povreda članka 6., stavka 1. kao i članka 13. zbog nedostatka pravnog lijeka u nacionalnom pravu koji bi omogućio podnositeljima zahtjeva da postignu izvršenje presude Državnog savjeta.

\subsubsection{Materijalne posljedice}

Od prevelike je važnosti da istinsko pravo na djelotvorni pravni lijek bude na raspolaganju strankama, dok opseg toga prava treba precizirati.

Prvo, „djelotvornost pravnih sredstava“ u smislu članka 13., naravno, ne ovisi o izvjesnosti povoljnog ishoda za podnositelja zahtjeva. Također, „državno tijelo“ iz ove odredbe ne treba biti sudsko tijelo, ali njegove ovlasti i jamstva koja predstavlja uzimaju se u obzir pri ocjeni djelotvornosti pravnog lijeka koje se ulaže pred tim tijelom..$^{50}$ Nadalje, svi pravni lijekovi dostupni u nacionalnom pravu mogu ispuniti zahtjeve iz članka 13. iako ih nijedan od njih samostalno ne ispunjava. ${ }^{51}$

Zatim, pravni lijek iz članka 13. „treba biti djelotvoran de facto i de iure“ ${ }^{.52}$ Prema tome, Sud nalaže državama pozitivnu obvezu opskrbljivanja internim pravnim lijekovima. ${ }^{53}$ Nadalje, država se obvezuje kroz pozitivnu obvezu donijeti "odgovarajuće i dostatne mjere" kako bi se osiguralo izvršenje sudske odluke, ${ }^{54}$ uključujući i izvršenje u okviru privatnih sporova. ${ }^{55}$

U europskoj sudskoj praksi, pravo na izvršenje ima veliki opseg: obuhvaća pravomoćna sudska rješenja, tj. rješenja protiv kojih nije dopuštena žalba ${ }^{56} \mathrm{i}$ obvezujuća rješenja ${ }^{57}$ u građanskim ${ }^{58}$ i u kaznenim stvarima. ${ }^{59}$ Neizvršenje presude predstavlja kršenje članka 6., stavka 1., bilo da je rezultat neprisutnosti uprave, ${ }^{60}$ sudskog službenika kao što je sudski ovršitelj ${ }^{61}$ ili same države. ${ }^{62}$ Izvršenje treba biti ,potpuno, savršeno, a ne djelomično“, a naknada zbog teške pogreške države, zbog toga što je odbila pružiti pomoć pri izvršenju sporne odluke, također ne može „nadoknaditi nedostatak u izvršenju presude“. ${ }^{63}$

50 Europski sud za zaštitu ljudskih prava, 27. ožujka 2003., Dactylidi protiv Grčke.

51 Europski sud za zaštitu ljudskih prava, 25. ožujka 1983., Silver $i$ drugi protiv Ujedinjenog Kraljevstva; Europski sud za zaštitu ljudskih prava, 15. studenog 1996., Chahal protiv Ujedinjenog Kraljevstva.

52 Europski sud za zaštitu ljudskih prava, 27. lipnja 2000., Ihlan protiv Turske.

53 Vidi, Preporuku (2003) 17 Vijeća Europe.

54 Europski sud za zaštitu ljudskih prava, 17. lipnja 2003., Ruianu protiv Rumunije.

55 Europski sud za zaštitu ljudskih prava, 22. lipnja 2004., Pini i Bertani protiv Rumunije.

56 Europski sud za zaštitu ljudskih prava, 18. travnja 2002., Ouzounis protiv Grčke.

57 Europski sud za zaštitu ljudskih prava, 28. lipnja 2001., Maillard Bous protiv Portugala.

58 Europski sud za zaštitu ljudskih prava, 19. ožujka 1997., prev.

59 Europski sud za zaštitu ljudskih prava, 8. travnja 2004., Assanidzé protiv Gruzije.

60 Europski sud za zaštitu ljudskih prava, 19. ožujka 1997., Hornsby.

61 Europski sud za zaštitu ljudskih prava, 11. siječnja 2001., M protiv Italije.

62 Europski sud za zaštitu ljudskih prava, 29. lipnja 2004., Zhovner protiv Ukrajine.

63 Europski sud za zaštitu ljudskih prava, 31. ožujka 2005., Matheus protiv Francuske. 
I konačno, Preporuka Vijeća Europe predviđa ovlast upravnog suda za određenje privremene mjere zaštite do okončanja postupka. Mjere obuhvaćaju i potpuno ili djelomično odlaganje izvršenja osporenog akta uprave, što omogućuje da ponovno uspostavi, i de facto i de iure, situaciju kakva bi postojala u „odsustvu“ akta uprave, odnosno da nemetne odgovarajuće obveze tijelu uprave. Bez mogućnosti odlaganja izvršenja upravnog akta koji se napada tužbom, upravni spor se može pokazati nedovoljno učinkovitim. To se posebno odnosi na situacije u kojima bi izvršenje osporenog akta uprave dovelo tužitelja u nepovratnu situaciju. Djelotvornost pravnog sredstva u smislu članka 13. Europske konvencija za zaštitu ljudskih prava i temeljnih sloboda između ostalog zavisi i od toga ima li suspenzivno djelovanje i je li ono automatsko ili ne. O tome je stav zauzeo i Europski sud za zaštitu ljudskih prava (Jabari protiv Turkse). U ovom smislu posebno je značajna i Preporuka (89) 8 Vijeća Europe o privremenoj sudskoj zaštiti u upravnom stvarima. Osnovno načelo Preporuke je jamstvo prava tužitelja da od suda ili drugog nadležnog tijela zatraži poduzimanje mjera privremene zaštite u odnosu na akt uprave.

\section{RAZUMNI ROK}

Među elementima poštenog suđenja, članak 6. stavak 1. navodi pravo podnositelja zahtjeva da se njihova tužba riješi u razumnom roku. ${ }^{64}$ Sud u Strasbourgu skreće pozornost na ovaj prirodni zahtjev u svojoj presudi Velikog vijeća od 26. listopada 2000. u predmetu Kudla protiv Poljske. Obveza koja se nalaže državama da u tom smislu u svoje nacionalne pravne sustave uvedu posebno pravno sredstvo koje će omogućiti stranci u postupku da se žali zbog prekomjernog trajanja postupka. Ova tvrdnja proizlazi iz kombinacije članaka 6. stavka 1. i članka 13. Konvencije.

Naime, pravo stranke u upravnom sporu može se mjeriti prema kriteriju brzine. Tako je Europska konvencija za zaštitu ljudskih prava odredila kriterij razumnog roka kao jednu od osnovnih značajki pravičnog suđenja. Jedno od temeljnih načela Europske konvencije za zaštitu ljudskih prava iz članka 6. stavka 1. jest pravo na pravično suđenje koje je proizvelo bogatu sudsku praksu. Po uzoru na taj članak, Europski je sud definirao pravo na suđenje u razumnom roku kao jedno od općih načela prava Europske unije. ${ }^{65}$ Tako se donošenje presude upravnog

64 Više o tome: Šikić, Marko, Pravo na suđenje u razumnom roku u postupcima pred Upravnim sudom Republike Hrvatske, Zbornik Pravnog fakulteta Sveučilišta u Rijeci, Rijeka, 2009., str. 333-372. Šikić, Marko, Vremenski okviri odlučivanja u Hrvatskom upravnom sporu, Zbornik radova Pravnog fakulteta u Splitu, Splitu, god. 47, 1/2010., str. 93-112

65 To objašnjava zašto je u većini europskih zemalja to jedno od ključnih i nezaobilaznih načela (Austrija, Španjolska, Estonija, Francuska, Velika Britanija, Grčka, Italija, Irska, Poljska, Slovenija), a u nekima i ustavna obveza (Njemačka, Republika Češka). Samo neke zemlje i dalje imaju zadršku kada je riječ o usvajanju posebnih propisa u tom području (Malta, Litva, Latvija, Cipar). 
suda u razumnom roku postavlja kao zajednički cilj, dok će njegovo ostvarenje nužno ovisiti o upotrijebljenim sredstvima, koja su ponekad nedostatna. ${ }^{66} \mathrm{U}$ većini slučajeva, kršenje prava na suđenje u razumnom roku ne predstavlja krivnju nego jednostavno disfunkciju, što dopušta pokretanje objektivne odgovornosti države za štetu. Dakle, donošenje sudske presude u razumnom roku od strane upravnog suca postavlja se kao zajednički cilj, dok će njegovo ostvarenje nužno ovisiti o upotrijebljenim sredstvima, koja su ponekad nedostatna. ${ }^{67}$

66 U nekim državama je pravo na suđenje u razumnom roku zaštićeno ustavom (Njemačka, Cipar, Malta). Zahtjev za brzinom ujedno je pridonio i racionalizaciji ustroja upravnog sudovanja kroz uspostavu novih tijela (sudova) za kontrolu (Austrija, Estonija, Francuska, Portugal), uspostavi postupaka za filtriranje tužbi (Austrija, Grčka, Švedska), pojednostavljenju ili čak modernizaciji postupka zajedno s razvojem alternativnih načina rješavanja sporova (Italija, Francuska) ili čak uspostavi sustava odgovornosti države za štetu. Izmjenama i dopunama Ustava iz 2000. godine, pravo na suđenje u razumnom roku uvedeno je kao ustavno pravo u hrvatski pravni sustav. Ustav Republike Hrvatske, u članku 29., stavku 1., propisuje kako svatko ima pravo da zakonom ustanovljen neovisan i nepristran sud pravično i u razumnom roku odluči o njegovim pravima ili obvezama, ili o sumnji, ili optužbi zbog kažnjivog djela. Nadalje, Ustavni zakon o Ustavnom sudu, u članku 63., stavku 1., propisuje da će Ustavni sud pokrenuti postupak po ustavnoj tužbi i prije nego što je iscrpljen pravni put, u slučaju kada o pravima i obvezama stranke ili sumnji ili optužbi zbog kažnjivog djela nije u razumnom roku odlučio sud, ili u slučaju kada se osporenim pojedinačnim aktom grubo vrijeđaju ustavna prava, a potpuno je razvidno da bi nepokretanjem ustavnosudskog postupka za podnositelja ustavne tužbe mogle nastati teške i nepopravljive posljedice. I Zakon o sudovima, u članku 27., propisuje zaštitu prava stranke na suđenje u razumnom roku. U kontekstu iznesenih tvrdnji, važno je spomenuti da Zakon o upravnim sporovima iz 2010. „razumni rok“ prožimlje kroz načelo učinkovitosti te navodi da će upravni sud upravni spor provesti brzo i bez odugovlačenja, uz izbjegavanje nepotrebnih troškova, onemogućit će zlouporabu prava stranaka i drugih sudionika u sporu te će odluku donijeti u razumnom roku. Zakon o upravnim sporovima iz 2010. predviđa kao predmet upravnog spora i ocjenu zakonitosti propuštanja javnopravnog tijela iz područja upravnog prava da u zakonom propisanom roku odluči o pravu, obvezi stranke, odnosno da postupi prema propisu. Razvidno je da se spomenutim propisima za pravo na pošteno suđenje obuhvaćaju standardi ostvarenja nečijih prava pred neovisnim i nepristranim sudom, uz obvezu vođenja pravičnog postupka koji će završiti u razumnom roku. Standarde (kriterije) koje je postavio Europski suda za određivanje pojma „razumnog roka“, prihvatili su Ustavni sud, redovni i specijalizirani sudovi zajedno s Vrhovnim sudom Republike Hrvatske, kada su oni postali nadležnima za pružanje zaštite u ovoj vrsti postupka. Sve spomenute kriterije sud ocjenjuje istovremeno te razmatra njihov učinak na duljinu trajanja postupka. Prva presuda Europskog suda u kojoj je utvrđena povreda Europske konvencije za zaštitu ljudskih prava od strane Republike Hrvatske donesena je 2001., a odnosi se upravo na povredu prava na suđenje u razumnom roku.

67 Đerđa ističe kako određivanje općeg značenja pojma „razumnog roka“ u rješavanju svih upravnih stvari zbog njihove specifičnosti i različitosti ne daje rezultate, pravodobno rješavanje najčešće se osigurava postavljanjem posebnih rokova za rješavanje ovih stvari $\mathrm{u}$ pojedinim upravnim područjima, koji su onda i prilagođeni specifičnostima u ovim područjima. Đerđa, Dario, Učinak europskih pravnih pravila na pravno normiranje upravnog postupka u Hrvatskoj, Zbornik radova Pravnog fakulteta, Split, god. 50, 2/2013., str. 419. Šikić navodi da razvoj instituta zaštite prava na suđenje u razumnom roku u Republici Hrvatskoj možemo promatrati od trenutka kada je Europska konvencija postala dio unutarnjeg pravnog poretka Republike Hrvatske i kada je Republiku Hrvatsku počela obvezivati i odredba članka 
Pod utjecajem prakse europskih sudova i sve veće aktualnosti pitanja trajanja sudskih postupaka, u mnogim je zemljama razmotreno uvođenje posebnih pravnih sredstava protiv prekomjernog trajanja postupka. U tom je smislu i donesena Preporuka (2010) 3 Vijeća Europe o djelotvornim pravnim sredstvima za predugo trajanje postupka. Preporuka ne definira konkretnije mjere koje bi država mogla ili trebala poduzeti, već ostaje na razini općih načela. Primjerice, država bi trebala utvrditi postupke koji nose poseban rizik od prekomjernog trajanja i utvrditi uzroke tomu. Isto tako, trebalo bi omogućiti djelotvorne pravne lijekove protiv prekomjernog trajanja postupka i to u svim etapama postupka u kojima se utvrđuju građanska prava i obveze ili izriču kaznene sankcije, osigurati naknadu štete, u iznosu koji je, u skladu s praksom Europskog suda za zaštitu ljudskih prava, itd.

\section{NEOVISNOST I NEPRISTRANOST UPRAVNOG SUCA}

Preuzimanje zahtjeva poštenog suđenja, osobito u pogledu objektivne i konkretne nepristranosti upravnog suca, provodi se kroz izravnu primjenu članka 6. stavka 1. Načelo prava na pošteno suđenje u smislu članka 6. stavka 1. znači da svatko ima pravo da neovisni i nepristrani sud ispita njegov slučaj. ${ }^{68}$

Potrebno je naglasiti da je nepristranost suca najvjerojatnije jedno od najvažnijih pitanja u državama članicama Europske unije. Ovo načelo potvrđuje svaka država u svom Ustavu (na primjer Slovenija, Rumunjska) ili u postupovnim zakonima ili izravno u statutima sudaca. Valja napomenuti da se dvije novije države članice Unije po tom pitanju pozivaju na Europsku konvenciju za zaštitu ljudskih prava kao izvor za pravila o nepristranosti, te na taj način vidimo jedan od izvora usklađenosti statusa sudaca uprave. Zbog toga je shvatljivo da se, kad se govori o nezavisnosti sudstva, općenito misli na nezavisnost u odnosu na političku vlast. Ali, iako je to najizravniji pojavni oblik problema, on nije i jedini, jer nezavisnost suca mora postojati: i prema njegovom društvenom okruženju, te prema bilo kojoj ideologiji, odnosno onoj koju sudac sam prihvaća. Nezavisni sudac je osoba koja će, poštujući zakon i pravo, uvijek dati prednost svojoj savjesti u odnosu na naredbe.

Sudačka neovisnost mora se smatrati pravom građana. Sudačka neovisnost „nije posebno pravo i povlastica u njegovu vlastitu interesu, nego u interesu vladavine prava i onih koji pravdu traže i koji je očekuju“ “. 99

6. Europske konvencije pod nazivom „Pravo na pošteno suđenje“. Ističe da je od navedenog trenutka započela prilično intenzivna zakonodavna aktivnost kojom se hrvatske građane željelo zaštititi od nerazumno dugih rokova rješavanja u sudskim postupcima. Šikić, Marko, Utjecaj prakse (presuda) Europskog suda za zaštitu ljudskih prava na upravno sudovanje u Republici Hrvatskoj, Zbornik radova Pravnog fakulteta, Split, god. 50, 2/2013., str. 458.

68 Vidi o tome i Ljubanović, Boris, Pošteno suđenje kao temelj sudačke etike, Zbornik radova Pravnog fakulteta u Splitu, god. 49, 3/2012., str. 449-457.

69 CCJE, Mišljenje br. 1 (2001.). 


\subsection{Značenje i stvarni domet sudske prakse}

Sudska praksa mora biti pregledna, dostupna u prvom redu upravnim sucima, ali i svim građanima, te kao takva mora pridonijeti ujednačenom rješavanju sudskih predmeta u istoj ili sličnoj činjeničnoj pravnoj situaciji, što će povećati sigurnost i ravnopravnost svih građana pred zakonom.

Sudska praksa omeđuju područje primjene pravnih tekstova i, ako je potrebno, ustanovljuju smisao pojedinih pojmova koje pravni tekstovi nisu definirali. Sudska praksa isto tako ispunjava pravne praznine koje mogu postojati u pravnom pravilu, te nalazi rješenja za ono što je ostalo nejasno. Ona otklanja proturječnosti koje su izmakle zakonodavcu i koje sprečavaju pravilnu primjenu tekstova. Ona odgovara na nove situacije, koje nastoji svesti na postojeće zakone, prilagođavajući zakon evoluciji društva, i osuvremenjavajući rješenja koja izvodi iz zastarjelih tekstova. I na koncu, sudska praksa oblikuje smjernična načela, koja ujedinjuju raznorodne tekstove, dajući im smisao i jedinstvo, na osnovi cjeline pozitivnog prava. Nitko ozbiljan danas ne stavlja u pitanje neophodnost sudske prakse, pa čak i za sam zakon, koji ne može biti trajno savršen (a često je zakon nesavršen od samog početka). Danas je sudska praksa, ${ }^{70}$ kao pravna i društvena potreba i nužnost, općenito prihvaćena. Sudska praksa nije samo pravni, već i društveni fenomen koji pridonosi koherentnosti pravne države.

\subsubsection{Uvjeti za uspješan dijalog između europskog i nacionalnog suca}

Izazov Europske konvencije za zaštitu ljudskih prava ${ }^{71}$ predstavlja pomirbu prava zajedničkog državama potpisnicama s njihovom nacionalnom autonomijom. Bilo da su to materijalna prava ili jamstva poštenog suđenja, posljednju riječ uvijek ima Sud u Strasbourgu. No, on je priznao da „ne može zanemariti utemeljenost i postupak pripadajućih nacionalnih prava“, ${ }^{72}$ te da Konvencija ne nalaže apsolutnu ujednačenost sudske prakse. Upravo zato dijalog sudaca je taj koji mora pomiriti koherentni europski pravni poredak i raznolikost nacionalnih sustava.

Suživot europskog pravnog poretka u cjelini i nacionalnih pravnih poredaka ne može se ostvariti bez sukoba. ${ }^{73}$ Jedno vrijeme se u doktrini i kod nekih praktičara moglo primijetiti da ,primjenjivost članka 6. pojašnjava izravno suprotstavljanje dvije nepomirljivo oprečne logike“" ${ }^{74}$ Sukobi koji su postojali izazivali su intelek-

70 O važnosti ujednačenosti sudske prakse vidi: Aviani, Damir, Đerđa, Dario, Uniformno tumačenje i primjena prava te jedinstvenost sudske prakse u upravnom sudovanju, Zbornik radova Pravnog fakulteta, Split, god. 49, 2/2012., str. 369-394.

71 Vidi Šikić, Marko, Utjecaj prakse (presuda) Europskog suda za zaštitu ljudskih prava na upravno sudovanje u Republici Hrvatskoj, Zbornik radova Pravnog fakulteta, Split, god. 50, 2/2013., str. 458.

72 Europski sud za zaštitu ljudskih prava, 26. travnja 1979., Sunday Times protiv Ujedinjenog Kraljevstva.

73 Chapus, Rene, str. 6.

74 Sermet, L., Bilan de la jurisprudence du Conseil d'Etat sur l'application de l'article 6 de la CEDH (précité), R.F.D.A., 5/1997, Paris, str. 1010. 
tualne rasprave koje su dovele do postupnih reformi koje su temeljito poremetile iskušane i dobro uspostavljene prakse, uz istovremeno promicanje zahtjeva za veću pravnu sigurnost. Danas smo nadišli ideju da odnosi s europskim sucem mogu biti samo konfliktne naravi, oslanjajući se na izgovor o relativnoj nestabilnosti i o pomanjkanju razumljivosti europske sudske prakse. Prepirke su omogućile da se postignu određene reforme, na koje se ponekad dugo čekalo, i da se isprave davno utvrđene nesavršenosti. Promjena je potvrdila ništavost oklijevanja i određeni zazor od primjene Europske konvencije za zaštitu ljudskih prava u svim njenim implikacijama.

Načelo je da su presude Suda u Strasbourgu obvezujuće i od država zahtijevaju da se prilagode konkretnim (pripadajućim) sporovima. Međutim, ako europski sudac utvrdi povredu Konvencije ili ako pruži „pravičnu zadovoljštinu, pa nema obvezu izmijeniti nacionalnu normu ili praksu koji su uzrok osudi; sloboda je prepuštena državama u pogledu sredstava koja će primijeniti pri izvršenju presude Suda“ ${ }^{75} \mathrm{Na}$ njima je da slobodno odlučuju o načinu izvršenja donesene presude, a nacionalni suci nisu dužni uskladiti svoju sudsku praksu s onom Suda u Strasbourgu, jer nisu u podređenom položaju u odnosu na Sud u Strasbourgu. Zapravo, postupak pokrenut pred Sudom u Strasbourgu ne predstavlja pravni lijek protiv pravomoćnih rješenja nacionalnih sudova.

\subsubsection{Podsjetnik na načelo supsidijarnosti ${ }^{76}$ kao utvrđeno ograničenje europskom sucu}

Kada nacionalni sudac samostalno, na ovaj ili onaj način, preuzme europsku sudsku praksu, to je zbog toga što joj daje određenu prednost. Dijalog sudaca predstavlja prednost koja se odnosi na otvaranje nacionalnih pravnih sustava jednih drugima, a europski sudac se, u načelu, nadahnjuje s onim najboljim što ima u svakom od njih, kako bi se postigla što veća dobrobit pravne države. Nastojeći utvrditi i uspostaviti zajednička postupovna pravila, Sud se oslanja na ,poticaj da njegova sudska praksa bude instrument za usklađivanje nacionalnih sustava ljudskih prava“". ${ }^{77}$ Cilj nije nametanje jedinstvenog sudskog modela već usklađivanje nacionalnih praksi, kroz provođenje odgovarajućih usporedbi koje se odnose na superiornost Konvencije i proglašenih subjektivnih prava i autonomnosti sustava čija je učinkovitost dokazana.

Prihvaćanje prava zajamčenih Europskom konvencijom, prema M. Guyomaru, ostvaruje se na tri načina: 1.) u nacionalnom (internom) pravu postoji jednakovrijedno pravo spojivo s europskim pravilom, pa je tada dovoljno primijeniti nacionalnu normu, eventualno u svjetlu zahtjeva Konvencije; 2.) nacionalno

75 Ibid.

76 O supsidijarnosti konvencijskog sustava vidi Jasna, Omejec, Konvencija za zaštitu ljudskih prava $i$ temeljnih sloboda u praksi Europskog suda za ljudska prava, Novi informator, Zagreb, 2013., str. 38-43.

77 Europski sud za zaštitu ljudskih prava, 18. siječnja 1978., Irska protiv Ujedinjenog Kraljevsta. 
(interno) pravo ne ispunjava sve europske zahtjeve, ali istovremeno nije nespojivo, pa se tada provodi kombinirana primjena nacionalne (interne) norme i europskog pravila, 3.) osporavano nacionalno (interno) pravilo ili pravilo na koje se poziva pokazuje se u potpunosti nespojivo sa zahtjevima Konvencije, te se kao takvo neće primijeniti. $^{78}$

Ako je uobičajeno da europska sudska praksa ima prednost, tada to ipak treba biti uravnoteženo, načelu supsidijarnosti, što je u osnovi konvencijskog sustava. Njezina logika temelji se na činjenici da je nacionalni sudac prvi jamac prava koja štiti Konvencija, a tek nakon što se iscrpe nacionalna pravna sredstva Europski sud može djelovati i supsidijarno. Time se nacionalnim sucima ostavlja slobodna procjena s obzirom na ravnotežu koju je potrebno uspostaviti između nacionalnih posebnosti i europskih zahtjeva, osim što se mogu pojaviti određena prirodna odstupanja. Mogućnost izjašanjavanja koja se na ovaj način daje nacionalnom sucu, a da pritom nije mehanički vezan sudskom praksom Europskog suda pridonosi dobrom djelovanju europskog sustava. Ako je suradnja s nacionalnim sudovima neophodna, supsidijarnost europskog djelovanja omogućuje nacionalnom sucu da pruži puni učinak konvencijskim zahtjevima. To dovodi do toga da ,je Sud pozvan da „govori“ o pravu, a da ne mora u svakom slučaju presuditi““. ${ }^{79}$ Očigledno i kako obraćanje Europskom sudu ne bi bilo bespredmetno, potrebno je da nacionalni upravni suci dobro poznaju svoju sudsku praksu.

Ova pravna struktura temelji se na lojalnoj suradnji između nacionalnih upravnih sudaca i europskog suca za zaštitu ljudskih prava. Nacionalni sudac može najbolje procjeniti doseg određene europske sudske prakse i njezine, eventualne nedostatke na nacionalnom planu, kao i prilagodbe koje je potrebno provesti. Europski sudac treba omogućiti da prevladaju temeljna načela poštenog suđenja. Međutim, to usklađivanje treba poštovati nacionalne specifičnosti jer posebnosti nacionalnih (internih) prava i raznolikost nacionalnih rješenja nisu nužno nespojiva s odredbama Konvencije. Legitimni ,pluralizam u okviru istog europskog javnog poretka nalaže da se nacionalna pravna stvarnost ne ocjenjuje u ime apstraktnih načela". 80

Nesporno je da je europsko pravo imalo ulogu zajedničkog jamca u zaštiti sloboda i temeljnih prava. I moguće je da je europske zemlje navelo da promisle i restrukturiraju svoje postupke. Komplementarnost nacionalne i europske sudske prakse dovela je do napredovanja pojma prava na pošteno suđenje. Ta je razmjena omogućila izgradnju novog prava proizašlog iz kretanja modela i međusobnog obogaćivanja sudskih praksa. Ovaj proces kojim se potiče djelovanje europskog i nacionalnog suca i koji pridonosi sve izraženijoj europskoj integraciji, omogućio je da se određene nacionalne posebnosti propituju ili mijenjaju. To može utjecati na

78 Guyomar, Mattias, Seiller, Bertrand, Contentieux administrative, Dalloz, Paris, 2014., str. 329.

79 Lichè, F., Potvin-Solis L., Raynouard, A., Le dialogue entre les juges européens et nationaux: incantation ou réalité ?, Bruxelles, Bruylant, 2004., str. 242.

80 Ibid. 
pravnu sigurnost u onoj mjeri u kojoj nacionalno pravo postaje složenije, određene institucije su destabilizirane, a pravni identitet se izlaže opasnosti da bude ublažen.

\subsection{Učinkovitost upravnosudske odluke prema snazi uvjerljivosti (obrazloženje)}

Obrazloženje sudskih odluka treba sagledavati kao instrument u službi stranaka te sredstvo sagledavanja pedagoških ciljeva.

Uvjeriti znači nekoga navesti da povjeruje, shvati i zatim usvoji. Uvjeravanje je sila koja zna koristiti jezik kao stvarni alat za uvjeravanje, što omogućuje više-manje potpuno prihvaćanje nekog načina razmišljanja, logike te $u$ apsolutnom smislu rješenja. Ako to primijenimo na sudsku odluku, snaga uvjeravanja znači da želimo postići da je prihvati onaj kome je upućena. Ali s obzirom na to da prihvaćanje stvara subjektivni pristanak, gotovo ,afektivni“ odnos, kako možemo prihvatiti neku sudsku odluku koja nam ne ide u prilog? U svakom slučaju, pojedinačno prihvaćanje koje se objektivno vezuje uz sudsku odluku postiže se putem mehanizma obrazloženja presude. Uistinu, kako prihvatiti sudsku odluku ako ona nije obrazložena, odnosno ako ne počiva na objektivno prihvatljivoj osnovi: pravu? Usprkos svemu, treba ići dalje u težnji za uvjeravanjem. Potrebno je razviti neki oblik pedagogije sudske odluke. Kako postići osjećaj prihvaćanja, ako ne kroz neophodni razvoj tog dodatnog instrumenta? To znači da obrazloženje sudske odluke stvara funkcionalnu dvojnost: istovremeno je okrenuta prema sebi time što dopušta sucu samoograničenje, ali isto tako i prema vani, odnosno prema strankama, budući da je lišena pedagoške funkcije. Obveza davanja obrazloženja djeluje prirodno utoliko što predstavlja neosporan element kvalitete pravosuđa. Ona je „obrana od arbitrarnog kojom se prisiljava suca da osvijesti svoje mišljenje, svoj domašaj (...) i da (među ostalim) stranci da obrazloženje svoje odluke“. Obrazloženje u konačnici mora jasno predočiti logiku kojom se koristio sudac i u tom smislu je ono obavezno.

Iako je obrazloženje temeljno načelo, prepoznato i prihvaćeno u svim pravosudnim sustavima. Obveza davanja obrazloženja ne spominje se izričito u formulaciji Europske konvencije za zaštitu ljudskih prava i bilo je potrebno tumačenje sudaca u Strasbourgu kako bi ona postala sastavni dio prava na pravično suđenje. Suci Suda u Strasbourgu dovode u vezu spomenutu obvezu, bilo s pravom na saslušanje predmeta pred sudom, bilo sa zahtjevom za njegovom nespristranošću. Europski sud za ljudska prava onda ocjenjuje in concreto poštovanje tog zahtjeva za obrazloženjem sudskih odluka u svjetlu specifičnih okolnosti karakterističnih za svaki predmet.

Međutim, točno je da su obrazloženje i silogistička logika najčešće prihvaćeni, a obrazloženje omogućuje sucu da ,utvrdi, definira i opravda premise kako bi došao do konačne odluke ili zaključka." Obrazloženje je u tom slučaju sastavni dio sudske logike, premisa koja omogućuje da se dođe do zaključka, način izražavanja čija je namjera opisati ,itinerer“ kojim idu suci, obvezujući ih da se ,,izraze na način koji 
pokazuje da postupaju u skladu s pravilima ispravne logike“. Obrazloženje presude je instrument u službi znanstvene logike koji prenosi njezinu „tehničku funkciju“.

Obrazloženje predstavlja „očitost“ presude jer je plod inteligentnog razmišljanja koje omogućuje konkretnu primjenu teorijskog načela. Sâmo iščitavanje razmišljanja tog tipa trebalo bi gotovo automatski dovesti do prihvaćanja. Pedagogija je nužno rezultat procesa logike suda, ali ako se držimo te konstatacije, pedagogija kojoj težimo nužno je okrenuta sama sebi dok se ne možemo zadovoljiti odlukom koja se smatra pravednom, budući da ljudski duh želi znati zašto je takva i kako je donesena. U obrazloženju sudske odluke treba paziti na poštovanje dvaju kriterija: biti pravna podloga za izreku i predstavljati sredstvo za razumijevanje koje koristi onome kome je namijenjeno. Ova dva zahtjeva u svojoj biti predstavljaju sastavni dio zadaće suda. Već smo rekli da su obrazloženje i objašnjenje usko povezani, budući da je obrazloženje sama bit silogističkog razmišljanja. Obrazloženje daje legitimitet odluci i ujedno je objašnjava. Drugim riječima, opseg obveze objašnjenja sagledava se isključivo iz perspektive legitimnosti: odluka je obrazložena, utemeljena u pravu i prema tome nužno shvaćena i prihvaćena.

Sudske bi odluke trebale sadržavati pisano obrazloženje, u kome se nalaze odgovori na sve argumente tužitelja i time se opravdava donesena odluka. Obim ove obveze u nacionalnim propisima razlikuje se i najviše zavisi prirodi odluke. Obrazloženje mora odgovarati činjenicama slučaja, a ne biti ograničeno samo na ponavljanje relevantnih odredaba propisa. Naravno, ne traži se detaljan odgovor na sve argumente, kao što je i Europski sud za zaštitu ljudskih prava potvrdio u presudi Ruiz Torija protiv Španjolske. U ovom predmetu žalbeni sud, koji je potvrdio presudu prvostupanjskog suda, nije ispitao jedan od argumenata koje je iznio tužitelj. Nedostatak ili neadekvatnost obrazloženja može biti razlog za poništenje odluke. Posebno je važna terminologija koja se koristi u obrazloženju odluke, da bi ih stranke mogle ispravno razumijeti. Treba posvetiti posebnu pažnju upotrebi termina iz stručne oblasti, jer to može biti neprikladno u kontekstu sudskog postupka.

\section{ZAKLJUČAK}

U najnovije vrijeme, pitanje prava stranke u upravnom sporu nameće se kao jedno od najvažnijih pravnih pitanje uopće. Zbog toga se sustav upravnog sudovanja, u cjelini, mora razmatrati kako bi se ocijenila učinkovitost pravne zaštite stranke u upravnom sporu. Tako se, pravo stranke u upravnom sporu, može promatrati samo kao ,proces“ koji se tiče donošenja pravične odluke.

Odluke donesene u postupku sudske kontrole moraju biti djelotvorne kako bi se pravima i interesima građana pružila istinska zaštita kako bi se osigurao kredibilitet sudova u društvu, kao i učinkovitost same uprave. Tako i sam hrvatski Zakon o upravnim sporovima, predviđa znatno veću i potpuniju zaštitu prava stranaka u upravnom sporu. 
Ne smijemo zaboraviti kako Europska unija sve sveobuhvatnije koristi ovlasti koje potiču na rastuću integraciju tako što pojedincima daje prava na koja se mogu izravno pozvati pred nacionalnim sudovima.

Iz svega navedenog možemo zaključiti kako upravno pravo Republike Hrvatske mora što sveobuhvatnije uključivati pravo koje razvija sud u Strasbourgu, a i pravo Europske unije koje razvije sud u Luxembourgu kako bi se strankama u upravnom sporu omogućila što učinkovitija zaštita njihovih prava i pravnih interesa. 


\section{Summary}

\section{THE INFLUENCE OF CONVENTION RIGHT AND EUROPEAN UNION LAW TO PROTECTION THE RIGHTS OF THE PARTIES IN THE ADMINISTRATIVE DISPUTE}

The aim of this paper was to determine the factors that affect the protection of the rights of the parties in the administrative dispute. Administrative courts in Croatia have in their activities at the same time include the right to develop the Court in Strasbourg and the right of a community to develop the Court in Luxembourg. To this end, the author discusses the impact of Convention rights and the rights of the European Union to protect the rights of the parties in administrative dispute.

Keywords: party, administrative dispute, convention right, European Union law.

\section{Zusammenfassung}

\section{AUSWIRKUNGEN DES KONVENTIONSRECHTS UND DER RECHTE DER EUROPÄISCHEN UNION AUF DEN KUNDENSCHUTZ IM VERWALTUNGSVERFAHREN}

Das Ziel dieser Arbeit ist es, die Faktoren zu bestimmen, die den Schutz der Kundenrechte im Verwaltungsstreit beeinflussen. Verwaltungsgerichte in Kroatien müssen in ihren Aktivitäten gleichzeitig das vom Gerichtshof in Straßburg entwickelte Recht einschließen, das als Konventionsrecht qualifiziert ist, und das vom Gerichtshof in Luxemburg entwickelte Gemeinschaftsrecht. Zu diesem Zweck beschreibt die Autorin die Auswirkungen der Konventionsrechte und des Rechts der Europäischen Union auf den Kundenschutz im Verwaltungsverfahren.

Schlüsselwörter: Kunden im Verwaltungsverfahren, Konventionsrecht, Recht der Europäischen Union. 


\section{Risassunto}

\section{L'INFLUENZA DEL DIRITTO CONVENZIONALE E DEL DIRITTO DELL'UNIONE EUROPEA SULLA TUTELA DEI DIRITTI DELLA PARTE PROCESSUALE NEL CONTENZIOSO AMMINISTRATIVO}

Lo scopo di questo lavoro è quello di accertare i fattori che influiscono sulla protezione dei diritti della parte processuale nel contenzioso amministrativo. I tribunali amministrativi nella Repubblica di Croazia debbono includere nel proprio operato allo stesso tempo sia il diritto che sviluppa la Corte di Strasburgo, qualificato come diritto convenzionale, come anche il diritto dell'Unione europea che invece sviluppa la Corte lussemburghese. A tale fine, l'autore disamina l'influenza del diritto convenzionale e del diritto dell'Unione europea sulla protezione dei diritti della parte processuale nel contenzioso amministrativo.

Parole chiave: diritti della parte processuale nel contenzioso amministrativo, diritto convenzionale, diritto dell'Unione europea. 